\title{
EXPLORATION OF MORINGA LEAVES EXTRACT AS SEED SOAKING AND FOLIAR TREATMENT FOR FABA BEAN
}

\author{
Fesal I. Yousof*, M.S. Abo El-Dahab, M.R. El-Mowafy and M.A. Abd-El-Aal \\ Seed Technol. Res. Dept., Field Crops Inst., ARC, Giza, Egypt
}

Received: 19/03/2017 ; Accepted: 30/05/2017

\begin{abstract}
Laboratory and field experiments were designed to investigate the influence of moringa leaves extract concentrations as seed soaking and foliar treatments on seed germination characters, field emergence, growth and yield as well as its attributes of faba bean (cv Sakha 1). Moringa leaves extract concentrations under study for both seed soaking and foliar treatments were $(0$, 5, 10 and $15 \mathrm{~g} / \mathrm{l}$ ). The results could be summarized as follows: Soaking faba bean seed in moringa leaves extract, generally recorded significant effect on all germination and seedling characters except germination (\%). Soaking faba bean seed in moringa leaves extract $(10 \mathrm{~g} / \mathrm{l})$ gave the highest values of field emergence (\%), emergence index and seedling characters compared with soaking in distilled water. Moringa leaves extract as a seed soaking treatment had significant effect only on branch $/ \mathrm{m}^{2}$ and seed yield $(\mathrm{kg} / \mathrm{fad})$. No significant differences of all characters under study were obtained between soaking seed in distilled water and soaking in moringa leaves extract concentration (5g/l). Application moringa leaves extract $(10 \mathrm{~g} / \mathrm{l})$ as a foliar in the field, recorded the highest values of growth and yield characters compared with control. It could be concluded that seed soaking and foliar application of moringa leaves extract concentration (10 g/l) was a successful way to improve field emergence and seed yield of faba bean (cv. Sakha 1).
\end{abstract}

Key words: Faba bean, moringa, leaves, extract, germination.

\section{INTRODUCTION}

Faba bean (Vicia faba L.) is a primary source of vegetable protein and carbohydrates in human food and animal feed. However, the total production of this crop is still insufficient to cover the local consumption. There is a great need to overcome this gab between local production and consumption demand. Moringa oleifera leaves extract (MLE) is considered one of the plant biostimulants, which are substances when applied as seed soaking and/or foliar spray positively modify plant growth (Rady et al., 2015). Moringa leaves extract can be recommended to be used effectively by farmers as a bio-organic fertilizer for various crops due to its high productivity, high nutritive value, antioxidant effect, easy preparation, low cost and environmentally friendly nature (Mona, 2013).
Basra et al. (2011) reported that priming maize seed with moringa leaves extract (MLE) diluted to 30 times with distilled water, enhanced seedlings traits and speed germination. Safi-naz and Rady (2015) demonstrated that moringa leaves extract application used as seed soaking or foliar spray, significantly increased growth characteristics (i.e., shoot length, number and area of leaves per plant, and plant dry weight), physio-chemical attributes (i.e., total chlorophylls, total carotenoids, total soluble sugars, free proline and ascorbic acid, contents of $\mathrm{N}, \mathrm{P}, \mathrm{K}$ and $\mathrm{Ca}$, and ratios of $\mathrm{K} / \mathrm{Na}$ and $\mathrm{Ca} / \mathrm{Na}$ ). According to Mehboob (2011) osmopriming of maize seed with moringa leaves extract reduced mean emergence time (MET) (8.967 vs. 9.097 days) and increased final emergence percentage (FEP) (83.33 vs. 86.333) under optimum compared to control.

\footnotetext{
*Corresponding author: Tel.: +201016322386

E-mail address: fysalyoussof@yahoo.com
} 
A plant growth spray made from moringa leaves increased crop production as such as 20$35 \%$, moringa extract spray improves the crops by heavier roots, stems and leaves, increasing in yield as much as 20-35\% (Foidle et al., 2001). Using MLE priming in wheat under normal conditions was found to be effective and improved the seedling emergence rate, speed, early growth, level of antioxidants, leaves total soluble protein and chlorophyll contents as compared to control (Yasmeen, 2011). The present study aimed to evaluate extract of moringa leaves as a seed soaking treatment and foliar spray treatment for improving emergence, growth and yield of faba bean.

\section{MATERIALS AND METHODS}

Laboratory and field experiments were carried out during 2014/2015 and 2015/2016 seasons at the Laboratory of Seed Technology
Research Unit, Mansoura and Experimental Farm of Tag Al-Ezz, Agric. Res. Station, ARC, Dakahlia Governorate, Egypt, to study the effect of moringa leaves extract with four concentrations $(0,5,10,15 \mathrm{~g} / \mathrm{l})$ as either seed soaking treatment or foliar application on field emergence, growth and yield of faba bean (cv Sakha 1). Seeds were obtained from Central Administration of Seed Production (CASP).

\section{Preparation of Moringa Leaves Extract}

Moringa leaves (Moringa oleifera) were cleaned thoroughly, dried in room temperature and then crushed into coarse powder and 5, 10 and $15 \mathrm{~g}$ of the powder were weighted and soaked separately in 1 liter of distilled water. All preparations were keept on a Shaker for 3 days. Then filtered through cheese cloth. Chemical composition of Moringa leaves extract according to US Department of Agriculture (2013) is shown in Table 1.

Table 1. Chemical composition of moringa leaves extract (100 g)

\begin{tabular}{lc}
\hline Nutrient & Amount in 100 grams \\
\hline Energy (Kcal, MJ) & 64 \\
Protein (g) & 9.4 \\
Carbohydrates (g) & 8.3 \\
Fiber, crude (g) & 2 \\
Ca (mg) & 185 \\
P (mg) & 112 \\
Na (mg) & 9 \\
K (mg) & 337 \\
Fe (mg) & 4 \\
Zn (mg) & 0.6 \\
Cu (mg) & 0.15 \\
Thiamin (mg) & 0.26 \\
Riboflavin (mg) & 0.66 \\
Vitamin B-6 (mg) & 1.2 \\
Vitamin A ( $\boldsymbol{\mu g}$ RAE) & 378 \\
Vitamin C (mg) & 52 \\
Vitamin E (mg) & 25 \\
\hline
\end{tabular}




\section{Laboratory Experiment}

Faba bean seeds were soaked in moringa leaves extract with concentrations (5, 10 and 15 $\mathrm{g} / \mathrm{l}$ ) and distilled water as a control for 6 hours before incubation in growth chamber at $20^{\circ} \mathrm{C}$ for 14 days and germination was observed daily to study the following characters:

1. Germination percentage (G\%): It was calculated by counting only normal seedlings 14 days after planting according to (ISTA Rules, 1999).

2. Speed germination index (SGI): It was calculated as described in the Association of Official Seed Analysis (AOSA, 1983).

3. Seedling length $(\mathrm{cm})$ : It was measured from ten normal seedlings, 14 days after planting.

4. Seedling dry weight (g): Ten seedlings were dried in hot-air oven at $85^{\circ} \mathrm{C}$ for 12 hours and weighted 14 days after planting.

\section{Field Experiment}

Two field experiments were conducted at Tag Al-Ezz, Agric. Res. Station. The preceding summer crop was rice (Oryza sativa L.) in both seasons. The soil of trial field was analyzed as shown in Table 2.

The experimental design was strip plot design with four replicates. The horizontal plots included the four seed soaking treatments with different concentrations of moringa leaves extract for $6 \mathrm{hr}$., as follows (Distilled water, 5 $\mathrm{g} / \mathrm{l}, 10 \mathrm{~g} / \mathrm{l}$ and $15 \mathrm{~g} / \mathrm{l})$.

The vertical plots were allocated to four moringa leaves extract foliar treatments as follows (Without foliar application, 5 g/l, 10 g/l and $15 \mathrm{~g} / \mathrm{l})$.

The area of each experimental plot was 10.5 $\mathrm{m}^{2}$, including five ridges each of 3.5 meters long and $60 \mathrm{~cm}$ width. Calcium super phosphate $\left(15.5 \% \mathrm{P}_{2} \mathrm{O}_{5}\right)$ was applied at a rate of $150 \mathrm{~kg} /$ faddan during the appropriate soil preparation and before sowing. Nitrogen fertilizer (in the form of urea $46.5 \%$ ) was applied at the rate of $15 \mathrm{~kg} \mathrm{~N} /$ fad., before the first irrigation. Seeds were sown on Nov. $10^{\text {th }}$ and $20^{\text {th }}$ at the first and second seasons, respectively in hills of $20 \mathrm{~cm}$ apart on one side of the ridge. Seeding rate was 2 seeds for hill, with approximate 70000 plant/fed and without replanting absent hills. Foliar application treatments applied twice, the first was at 20 days after sowing and the second was at 30 days after sowing using 1.5 liter of solution for each experimental plot.

\section{Field Measurements}

1.Field emergence (\%): It was determined after 14 days from planting 400 seeds at area of 1.0 $\mathrm{m}^{2}$.

2.Field emergence Index (FEI): In this index, the higher the value, the better the field conditions until FEI=1.0, so that $\mathrm{FE}=\mathrm{G}$ (ideal). The field emergence index for each experiment was calculated based on the procedure used by Egli and Tekrony (1996) according to the following equation:

$$
F E I=\frac{F E}{G}
$$

Where:

$\mathrm{FEI}=$ Field emergence index; $\mathrm{FE}=$ Mean seedling field emergence of all seed lots; $\mathrm{G}=$ Mean standard germination of all seed lots.

\section{Growth and Yield Characters}

Ten plants were randomly chosen from the central ridges of each plot at harvest to estimate plant height $(\mathrm{cm})$, branch number /plant, pod number /plant and seed weight/plant. Branch number/ $\mathrm{m}^{2}$ were estimated by counting number of branch in 8 hills and seed yield (kg/fad.) was harvested from plot $\left(10.5 \mathrm{~m}^{2}\right)$ for each treatment.

All obtained data were subjected to the statistical analysis according to the technique of analysis of variance (ANOVA) of completely randomized design for laboratory experiment and strip plot design for the field experiment, as described by Gomez and Gomez (1984).

\section{RESULTS}

Seed germination percentage, field emergence (\%), field emergence index, speed germination index, seedling length $(\mathrm{cm})$ and seedling dry weight ( $\mathrm{g}$ ) of faba bean during two seasons are shown in Tables 3 and 4. Pre-sowing soaking of faba bean seeds with moringa extract at concentration (10 g/l) was superior in field emergence (\%) and emergence index compared 
Table 2. Chemical analysis of soil at experimental site in 2014/15 and 2015/16 seasons

\begin{tabular}{lcccccc}
\hline & $\begin{array}{c}\text { Organic } \\
\text { matter (\%) }\end{array}$ & $\begin{array}{c}\text { Salinity } \\
\text { dS/m }\end{array}$ & PH & $\begin{array}{c}\text { Available } \\
\text { N (ppm) }\end{array}$ & $\begin{array}{c}\text { Available P } \\
\text { (ppm) }\end{array}$ & $\begin{array}{c}\text { Exchangeable } \\
\text { K (ppm) }\end{array}$ \\
\hline Season 2014/15 & 1.8 & 1.9 & 7.7 & 31.6 & 5.4 & 223 \\
Season 2015/16 & 1.7 & 2.2 & 8.2 & 30.5 & 3.8 & 217 \\
\hline
\end{tabular}

Table 3. Germination (\%), field emergence (\%) and field emergence index of Sakha 1 faba bean cultivar as affected by seed soaking in moringa leaves extract concentrations in both seasons (2014-15, 2015-16)

\begin{tabular}{|c|c|c|c|c|c|c|}
\hline \multirow{2}{*}{$\begin{array}{l}\text { Moringa leaves extract } \\
\text { concentration }\end{array}$} & \multicolumn{2}{|c|}{ Germination (\%) } & \multicolumn{2}{|c|}{ Field emergence (\%) } & \multicolumn{2}{|c|}{ Field emergence index } \\
\hline & $2014 / 2015$ & $2015 / 2016$ & $2014 / 2015$ & $2015 / 2016$ & $2014 / 2015$ & $2015 / 2016$ \\
\hline \multicolumn{7}{|l|}{ Soaking } \\
\hline Distilled water & 92 & 90 & 87 & 85 & 0.95 & 0.94 \\
\hline $5 \mathrm{~g} / \mathrm{l}$ & 92 & 91 & 88 & 86 & 0.96 & 0.95 \\
\hline $10 \mathrm{~g} / \mathrm{l}$ & 92 & 91 & 90 & 88 & 0.98 & 0.97 \\
\hline $15 \mathrm{~g} / \mathrm{l}$ & 89 & 89 & 83 & 82 & 0.93 & 0.92 \\
\hline F. test & NS & NS & $* *$ & $* *$ & $* *$ & $* *$ \\
\hline LSD at $5 \%$ & - & - & 3 & 2 & 0.02 & 0.02 \\
\hline
\end{tabular}

Table 4. Speed germination index, seedling length $(\mathrm{cm})$ and seedling dry weight $(\mathrm{g})$ of Sakha 1 faba bean cultivar as affected by seed soaking in moringa leaves extract concentrations in both seasons (2014-15, 2015-16)

\begin{tabular}{|c|c|c|c|c|c|c|}
\hline \multirow{2}{*}{$\begin{array}{l}\text { Moringa leaves extract } \\
\text { concentration }\end{array}$} & \multicolumn{2}{|c|}{ Speed germination index } & \multicolumn{2}{|c|}{ Seedling length $(\mathrm{cm})$} & \multicolumn{2}{|c|}{ Seedling dry weight (g) } \\
\hline & $2014 / 2015$ & $2015 / 2016$ & $2014 / 2015$ & $2015 / 2016$ & $2014 / 2015$ & $2015 / 2016$ \\
\hline \multicolumn{7}{|l|}{ Soaking } \\
\hline Distilled water & 20.8 & 20.2 & 23.0 & 22.6 & 0.298 & 0.294 \\
\hline $5 \mathrm{~g} / \mathrm{l}$ & 21.5 & 20.7 & 23.5 & 23.0 & 0.307 & 0.302 \\
\hline $10 \mathrm{~g} / \mathrm{l}$ & 23.5 & 23.0 & 25.2 & 24.3 & 0.319 & 0.316 \\
\hline $15 \mathrm{~g} / \mathrm{l}$ & 19.8 & 19.2 & 21.9 & 21.0 & 0.284 & 0.282 \\
\hline F. test & $* *$ & $* *$ & $* *$ & $* *$ & $* *$ & $* *$ \\
\hline LSD at $5 \%$ & 0.8 & 0.6 & 0.7 & 0.6 & 0.011 & 0.010 \\
\hline
\end{tabular}


with other concentrations. Also, $10 \mathrm{~g} / \mathrm{l}$ concentration recorded the fastest speed germination index, tallest seedling length and heaviest seedling dry weight. On contrast, (15 g/l) moringa leaves extract concentration gave the lowest values of mentioned parameters in Table 3. Germination (\%) didn't affect by moringa leaves extracts as a seed soaking treatment. No significant differences of characters in Tables 3 and 4 were obtained between soaking faba bean seed with $(5 \mathrm{~g} / \mathrm{l})$ moringa leaves extract and distilled water.

Tables 5 and 6 shows plant height $(\mathrm{cm})$, branch number/plant, branch number $/ \mathrm{m}^{2}$, seed weight (g)/plant, pod number/plant and seed yield (kg/fad.) characters of Sakha 1 faba bean cultivar as affected by moringa extract solution as seed soaking and foliar application. Moringa extract concentrations as a seed soaking treatment gave insignificant effect on all characters in Tables 5 and 6 except branch number $/ \mathrm{m}^{2}$ and seed yield ( $\mathrm{kg} / \mathrm{fad}$.) characters. Soaking faba bean seeds in moringa leaves extract at $(10 \mathrm{~g} / \mathrm{l})$ significantly exceeded the other seed treatments in branch number/ $\mathrm{m}^{2}$ and seed yield ( $\mathrm{kg} / \mathrm{fad}$.) but, lowest values of all characters in Tables 5 and 6 were obtained by concentration (15 g/l) of moringa leaves extract as a seed treatment. Also, in branch number $/ \mathrm{m}^{2}$ and seed yield (kg/fad.) characters no significant differences were obtained between soaking faba bean seed with concentration (5 g/l) moringa leaves extract and distilled water treatment. With respect to moringa leaves extract as a foliar treatment, all characters in Tables 5 and 6 were significantly affected and concentration $(10 \mathrm{~g} / \mathrm{l})$ of foliar moringa gave the similar behavior of the same concentration as a seed soaking treatment, which was superior compared with other foliar treatments.

Results in Table 7 clearly shows that the interaction between moringa extract solution as a seed treatment and foliar treatment recorded significant effect on branch number $/ \mathrm{m}^{2}$ and seed yield ( $\mathrm{kg} / \mathrm{fad}$.) in both seasons under study. Both soaking and foliar faba bean with moringa extract solution at concentration $(10 \mathrm{~g} / \mathrm{l})$ gave the highest values of branch number $/ \mathrm{m}^{2}$ and seed yield ( $\mathrm{kg} / \mathrm{fad}$.) in both seasons under study. While, soaking and foliar faba bean with moringa extract solution at concentration $(15 \mathrm{~g} / \mathrm{l})$ produce the lowest values of previous mentioned characters.

\section{DISCUSSION}

Soaking faba bean seed in moringa leaves extract in concentration $(10 \mathrm{~g} / \mathrm{l})$ as a pre-sowing treatment succeeded to promote germination index, field emergence (\%), field emergence index and seedling characters as shown in Tables 3 and 4 and these results agreed with those of Noman (2008) who used moringa leaves extract as priming agent in hybrid maize and recorded increasing in germination speed and seedling vigor. Also, Phiri (2010) found that priming with moringa extract solution increased germination of sorghum, length of maize radicals and hypocotyls of wheat

Also, moringa extract solution as a field treatment in concentration $(10 \mathrm{~g} / \mathrm{l})$ recorded good results. Several workers reported that using moringa extract solution as a field treatment is effective, it may be due to that moringa extract is a natural source of cytokinin, moringa leaves is also rich in ascorbates, carotenoids, potassium and have plant growth promoting capabilities and often applied as exogenous plant growth enhancers (Foidle et al., 2001). Siddhuraju and Becker (2003) studied the antioxidants properties of moringa leaves extract and demonstrated that it: reduced potassium ferricyanide, scavenged superoxide radicals, prevented the peroxidation of lipid membrane in liposomes, could donate hydrogen and scavenge radicals. The effectiveness of moringa is because its leaves are rich source of PGR hormone, zeatin, ascorbic acid, $\mathrm{Ca}$ and $\mathrm{K}$. Moringa leaves are potential source of vitamin $\mathrm{A}$ and $\mathrm{C}$, iron, calcium, riboflavin, beta-carotene and phenolic acid (Nambiar et al., 2005). some assessments in moringa leaves as follow, 40139 $\mu \mathrm{g} / 100 \mathrm{~g}$ total carotenoides on fresh weight basis in moringa leaves , $19210 \mu \mathrm{g} / 100 \mathrm{~g}$ was $\beta$ carotene. Ascorbic acid at $6.6 \mathrm{mg} / \mathrm{g}$ on dry weight basis, $0.26 \mathrm{mg} / \mathrm{g} \mathrm{Fe}, 22.4 \mathrm{mg} / \mathrm{g}$ calcium, $6.3 \mathrm{mg} / \mathrm{g} \mathrm{P}, 11.2 \mathrm{mg} / \mathrm{g}$ oxallic acid and $0.9 \mathrm{~g} / 100$ $\mathrm{g}$ fiber (Yasmeen, 2011). It was noted that increasing concentration of moringa extract to $15 \mathrm{~g} / \mathrm{l}$ recorded negative effect on germination characters, it may be due to allelochemicals released from moringa, which inhibited the rate of germination (Moktar Hossain et al., 2012). It could be concluded that seed soaking and foliar application with moringa leaves extract concentration $(10 \mathrm{~g} / \mathrm{l})$ is effective in improving emergence, growth and yield characters of faba bean. 
Table 5. Plant height (cm), branch number/plant and branch number $/ \mathrm{m}^{2}$ of Sakha 1 faba bean cultivar as affected by moringa leaves extract concentrations as a seed soaking and foliar in both seasons(2014-15, 2015-16)

\begin{tabular}{|c|c|c|c|c|c|c|}
\hline \multirow{2}{*}{$\begin{array}{l}\text { Moringa leaves extract } \\
\text { concentration }\end{array}$} & \multicolumn{2}{|c|}{ Plant height (cm) } & \multicolumn{2}{|c|}{ Branch number/plant } & \multicolumn{2}{|c|}{ Branch number $/ \mathbf{m}^{2}$} \\
\hline & $2014 / 2015$ & $2015 / 2016$ & $2014 / 2015$ & $2015 / 2016$ & $2014 / 2015$ & $2015 / 2016$ \\
\hline \multicolumn{7}{|l|}{$\overline{\text { Seed soaking }}$} \\
\hline Distilled water & 86.9 & 86.5 & 3.6 & 3.5 & 44.9 & 44.1 \\
\hline $5 \mathrm{~g} / \mathrm{l}$ & 87.0 & 86.6 & 3.6 & 3.5 & 45.8 & 44.6 \\
\hline $10 \mathrm{~g} / \mathrm{l}$ & 87.0 & 86.8 & 3.6 & 3.5 & 47.4 & 46.5 \\
\hline $15 \mathrm{~g} / \mathrm{l}$ & 86.3 & 85.9 & 3.5 & 3.4 & 40.4 & 38.9 \\
\hline F. test & NS & NS & NS & NS & $* *$ & $* *$ \\
\hline LSD at $5 \%$ & - & - & - & - & 1.0 & 0.9 \\
\hline \multicolumn{7}{|l|}{ Foliar application } \\
\hline Without & 86.6 & 86.2 & 3.5 & 3.4 & 43.7 & 43.7 \\
\hline $5 \mathrm{~g} / \mathrm{l}$ & 87.1 & 86.7 & 3.6 & 3.5 & 44.7 & 43.7 \\
\hline $10 \mathrm{~g} / \mathrm{l}$ & 88.1 & 87.6 & 3.8 & 3.6 & 47.8 & 45.5 \\
\hline $15 \mathrm{~g} / \mathrm{l}$ & 85.6 & 85.1 & 3.5 & 3.3 & 42.2 & 41.1 \\
\hline F. test & $* *$ & $* *$ & * & $*$ & * & * \\
\hline LSD at $5 \%$ & 0.8 & 0.6 & 0.2 & 0.1 & 1.8 & 1.5 \\
\hline
\end{tabular}

Table 6. Seed weight (g)/plant, pod number/plant and seed yield (kg/fad.) of Sakha 1 faba bean cultivar as affected by moringa leaves extract concentrations as a seed soaking and foliar in both seasons(2014-15, 2015-16)

\begin{tabular}{lcccccc}
\hline Moringa leaves extract & Seed weight (g)/plant & Pod number/plant & Seed yield (kg/fad.) \\
\cline { 2 - 7 } concentration & $\mathbf{2 0 1 4 / 2 0 1 5}$ & $\mathbf{2 0 1 5} / \mathbf{2 0 1 6}$ & $\mathbf{2 0 1 4} / \mathbf{2 0 1 5}$ & $\mathbf{2 0 1 5} / \mathbf{2 0 1 6}$ & $\mathbf{2 0 1 4 / 2 0 1 5}$ & $\mathbf{2 0 1 5 / 2 0 1 6}$ \\
\hline Seed soaking & & & & & & \\
Distilled water & 22.4 & 21.7 & 18.5 & 18.0 & 1242 & 1177 \\
$\mathbf{5}$ g/l & 22.5 & 21.9 & 18.5 & 18.0 & 1255 & 1196 \\
$\mathbf{1 0}$ g/l & 22.5 & 22.0 & 18.6 & 18.1 & 1315 & 1270 \\
$\mathbf{1 5}$ g/l & 21.8 & 21.7 & 18.3 & 17.9 & 1116 & 1061 \\
F. test & NS & NS & NS & NS & $* *$ & $* *$ \\
LSD at 5\% & - & - & - & - & 28 & 25 \\
Foliar application & & & & & & \\
Without & 22.1 & 21.5 & 18.2 & 17.5 & 1220 & 1165 \\
$\mathbf{5}$ g/l & 22.5 & 22.1 & 18.5 & 17.9 & 1241 & 1182 \\
$\mathbf{1 0}$ g/l & 23.1 & 22.6 & 19.5 & 18.9 & 1273 & 1212 \\
$\mathbf{1 5}$ g/l & 21.7 & 21.2 & 17.7 & 17.3 & 1195 & 1146 \\
F. test & $* *$ & $* *$ & $* *$ & $* *$ & $* *$ & $* *$ \\
LSD at 5\% & 0.5 & 0.4 & 0.8 & 0.8 & 29 & 27 \\
\hline
\end{tabular}


Table 7. Branch number $/ \mathrm{m}^{2}$ and seed yield (kg/fad.) of Sakha 1 faba bean cultivar as affected by interaction between moringa extract solution as a seed soaking and foliar in both seasons

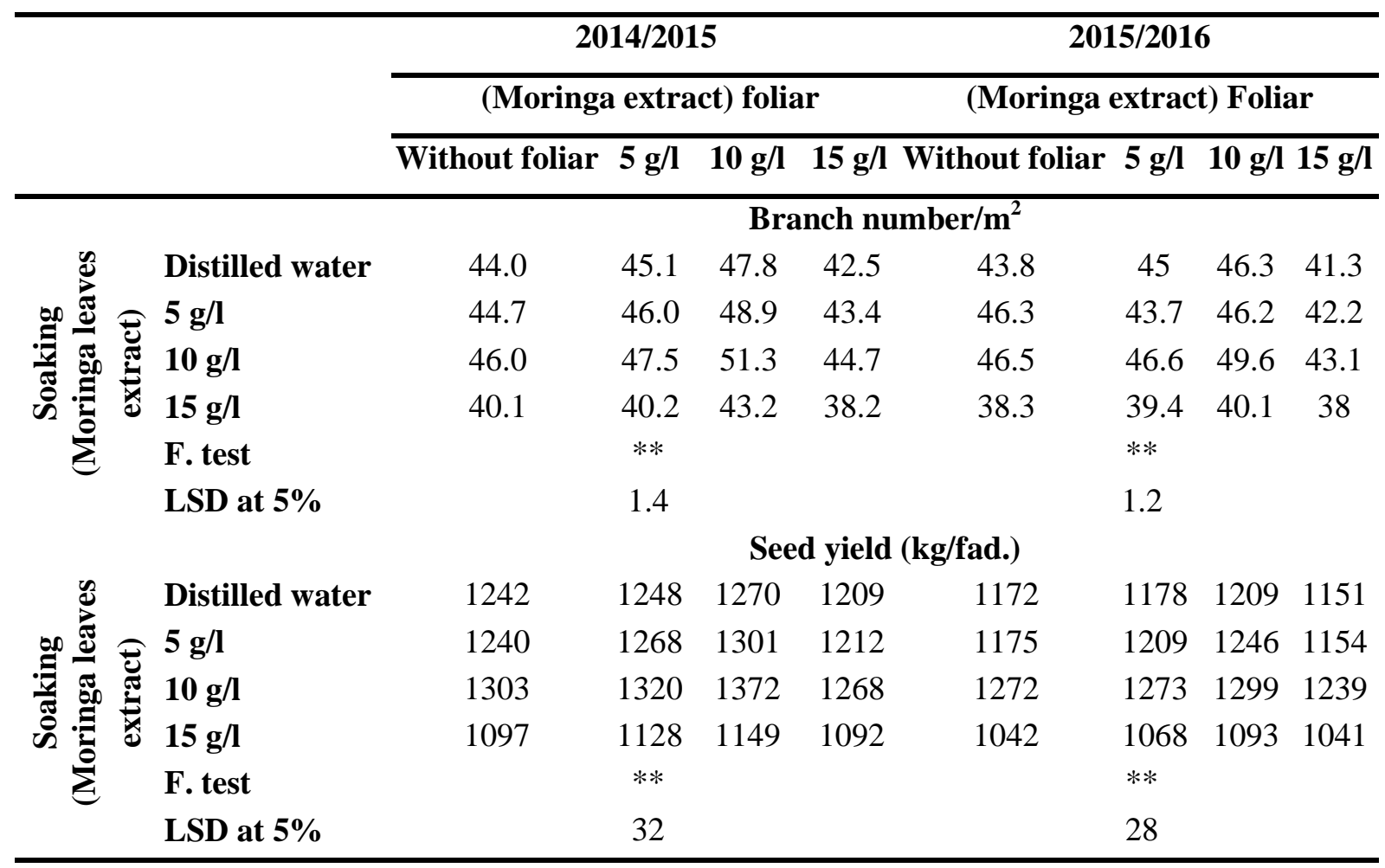

\section{REFERENCES}

AOSA (1983). Seed Vigor Testing Handbook. Contribution No.32 to the Handbook on Seed Testing.

Basra, S.M.A., M.N. Iftikhar and I. Afzal (2011). Potential of moringa (Moringa oleifera) leaves extract as priming agent for hybrid maize seeds. Int. J. Agric. Biol., 13 (6): 1006-1010.

Egli, D.B. and D.M. Tekrony (1996). Seedbed conditions and prediction of field emergence of soybean seed. J. Prod. Agric., 9 : 365370.

Foidle, N., H.P.S. Makkar and K. Becker (2001). The Potential of Moringa oleifera for Agricultural and Industrial Uses. 45-76. In L. Fuglie (ed.) the miracle tree: The multipurpose attributes of moringa. CTA publications. Wageningen, the Netherlands.
Gomez, K.A. and A.A. Gomez (1984). Statistical Producer for Agricultural Research $2^{\text {nd }}$ Ed., John Wiley and Sons.

ISTA Rules (1999). International Rules for Seed Testing . Seed Science and Technol. Proc. Int. Seed Test. Ass., 31 (1): 1-152.

Mehboob, W. (2011). Physiological evaluation of primed maize seed under late sown conditions. M.Sc. Thesis, Crop Physiol. Dept., Agric. Univ., Faisalabad.

Moktar H., M.G. Miah, T. Ahamed and S.N. Sarmin (2012). Allelopathic effect of Moringa oleifera on the germination of Vigna radiate. Int. J. Agric. Crop Sci., 4 (3): 114-121.

Mona, M.A. (2013). The potential of Moringa oleifera extract as a biostimulant in enhancing the growth, biochemical and hormonal contents in rocket (Eruca vesicaria subsp. sativa) plants. Int. J. Pl. Physiol. and Biochem., 5 (3): $42-49$. 
Nambiar, V.S., R. Mehta and M. Daniel (2005). Polyphenol content of three Indian green leavesy vegetables. J. Food Sci. Technol., 42 (6) :312-315.

Noman, I. (2008). Efficacy of moringa leaves extract as seed priming agent in hybrid maize. M.Sc. (Hons.) Thesis, Crop Physiol. Dept., Agric. Univ., Faisalabad.

Phiri, C. (2010). Influence of Moringa oleifera leaves extracts on germination and early seedling development of major cereals. Agric. Biol. J. N. Am., 1(5): 774-777.

Rady, M. M., G.F. Mohamed, A.M. Abdalla and H.M.A. Yasmin (2015). Integrated application of salicylic acid and Moringa oleifera leaves extract alleviates the saltinduced adverse effects in common bean plants, Int. J. Agric. Technol., 11 (7): 1595 1614.

Safi-naz, S.Z. and M.M. Rady (2015). Moringa oleifera leaves extract improves growth, physiochemical attributes, antioxidant defense system and yields of salt-stressed Phaseolus vulgaris L. plants. Int. J. Chem. Tech. Res., 8 (11): 120-134.

Siddhuraju, P. and K. Becker (2003). Antioxidant properties of various solvent extracts of total phenolic constituents from three different agro climatic origins of drumstick tree (Moringa oleifera Lam.) leaves. J. Agric. Food Chem., 51: 2144 -2155.

USDA (2013). U.S. Department of Agriculture, Agricultural Research Service national nutrient database for standard reference, release 25. http://ndb.nal.usda.gov/ Updated 2012. Accessed March,.

Yasmeen, A. (2011). Exploring the potential of moringa (Moringa oleifera) leaves extract as natural plant growth enhancer. Ph.D. Thesis, Agron. Agric. Univ. Faisalabad, Pakistan.

\section{استكشاف مستخلص أوراق المورينجا كمعاملة نقع تقاوي ورش للقول البلدي \\ فيصل إبراهيم يوسف ـ مجدي سعد الدين أبو الدهب \\ محمد رضا عبد السميع الموافي - مصطفى عبد الجليل عبد العال

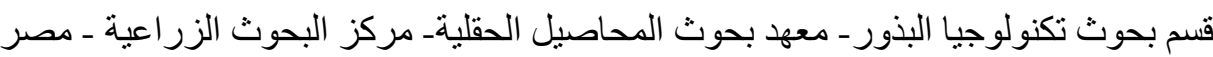

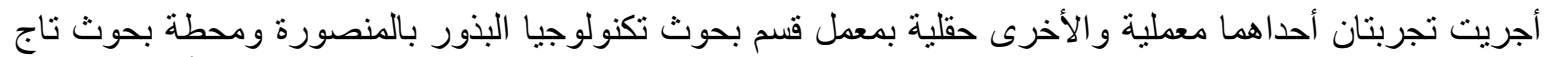

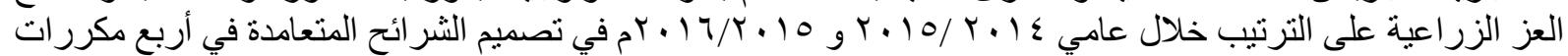

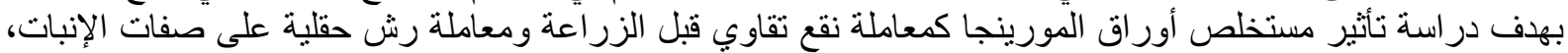

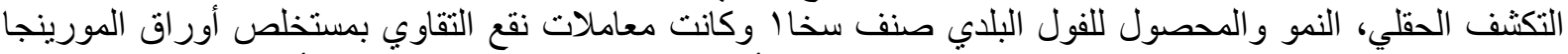

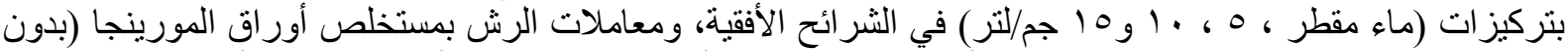

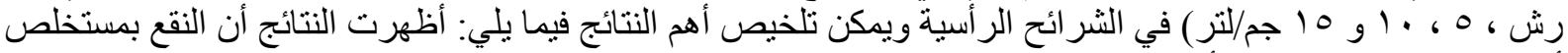

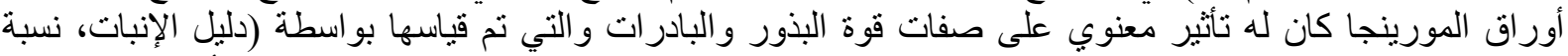

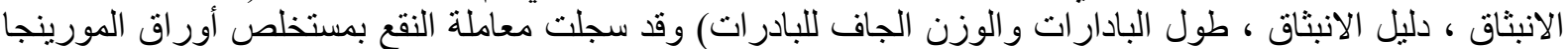

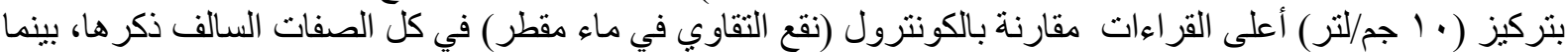

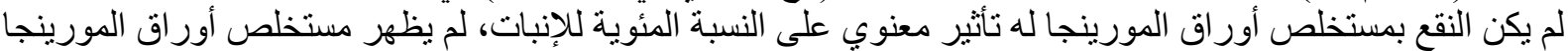

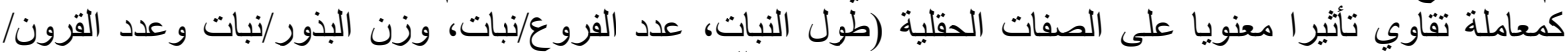

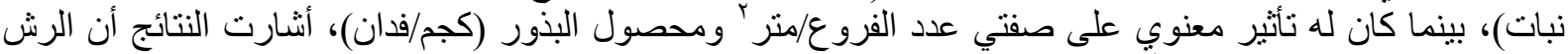

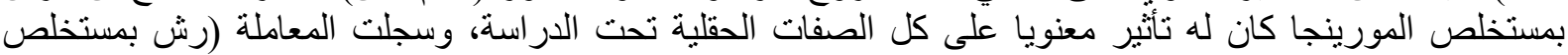

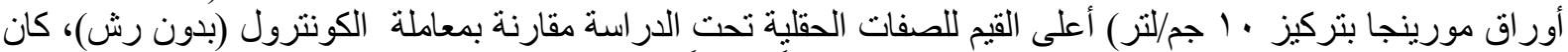

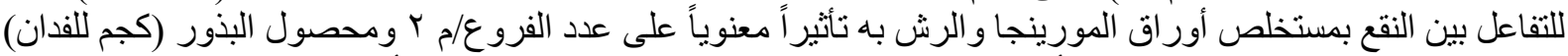

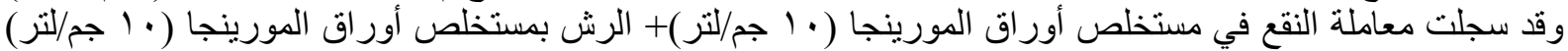

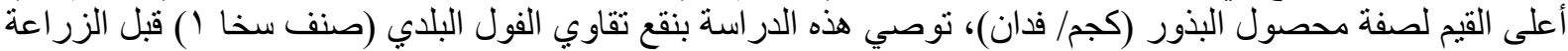

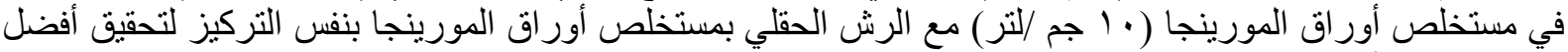
تكثف حقلي و أعلى إنتاجية لمحصول الفول البلدي تحت ظروف الترف محافظة الدقهلية.

أستاذ المحاصيل ـ مركز البحوث الزر اعية ـ مصر. أستاذ المحاصيل - كلية الزر اعة - جامعة الزقازيق. 